\title{
Increasing labor income and real unit labor costs in Brazilian agrobusiness
}

\author{
Rendimentos e custo unitário real do trabalho no agronegócio \\ brasileiro \\ Nicole Rennó Castro (D), Geraldo Sant'Ana de Camargo Barros² (i)
}

${ }^{1}$ Departamento de Ciências Econômicas (DCECO), Universidade Federal de São João Del Rei (UFSJ), São João Del Rei (MG), Brasil. E-mail: nicole.renno@cepea.org.br.

${ }^{2}$ Centro de Estudos Avançados em Economia Aplicada (CEPEA), Escola Superior de Agricultura "Luiz de Queiroz" (ESALQ), Universidade de São Paulo (USP), Piracicaba (SP), Brasil. E-mail: gscbarro@usp.br

How to cite: Castro, N. R., \& Barros, G. S. C. (2022). Increasing labor income and real unit labor costs in Brazilian agrobusiness. Revista de Economia e Sociologia Rural, 60(2), e233852. https://doi.org/10.1590/1806-9479.2021.233852

\begin{abstract}
This study analyzes the interactions between per worker labor income (PWLI), labor productivity, real unit labor costs, and the relationship between relevant employee (IPCA) and employers (GDP deflators) prices, specifically focusing on Brazilian agrobusiness. For that purpose, labor productivities of the entire agrobusiness sector and its segments were calculated from 2004 through 2015. We found that the gap between agrobusiness sector deflators and the IPCA did not play a preponderant role to mitigate the effect of PWLI growth of $3.81 \%$ annually on real unit labor cost (CURT), which only increased $0.21 \%$ annually. In turn, CURT was contained by productivity gains, boosted mainly by agriculture. Without this productivity growth, CURT would have increased at 3.7\% annually, thus making unviable the observed simultaneous gains for employers and employees in the Brazilian agrobusiness sector. The result for the primary agrobusiness segment should be highlighted. Even with an annual increase of $4.07 \%$ in PWLI, the $7.24 \%$ annual growth in productivity implied on an average annual reduction in CURT (-2.56\%); without this significant productivity growth, the same increase in PWLI would have boosted CURT by $4.7 \%$ annually.
\end{abstract}

Keywords: agrobusiness, labor productivity, unit labor costs, relative prices.

Resumo: Este estudo avalia, com foco no agronegócio, as interações entre a renda do trabalho por trabalhador (PWLI), a produtividade e os custos unitários reais do trabalho, bem como a relação entre os preços relevantes para empregados (IPCA) e empregadores (deflatores do PIB) no setor. Para isso, foi necessário calcular as produtividades do trabalho do agronegócio e seus segmentos para o período de 2004 a 2015. Verificou-se que o distanciamento entre deflator do PIB e IPCA não teve papel preponderante para mitigar o efeito do crescimento da PWLI, de 3,81\% a.a., sobre o custo unitário real do trabalho (CURT), que aumentou apenas $0,21 \%$ a.a. O CURT foi contido por ganhos de produtividade no setor, impulsionados principalmente pela agropecuária. Sem esses aumentos de produtividade, o CURT teria aumentado 3,7\% a.a., inviabilizando os ganhos simultâneos de empregadores e empregados do agronegócio. O resultado do segmento primário se destacou: mesmo com aumento de 4,07\% a.a. na PWLI, o crescimento anual de 7,24\% da produtividade implicou em redução média anual do CURT (2,56\%); sem esse significativo crescimento da produtividade, o aumento da PWLI teria impulsionado o CURT, que teria crescido 4,7\% a.a.

Palavras-chave: agronegócio, produtividade do trabalho, custo unitário do trabalho, preços relativos.

\section{INTRODUCTION}

In the period from 2004 to 2011, the relative price of agrobusiness products decreased by $5 \%$, while the sector's average per worker labor income (PWLI) increased by $31.2 \%$ in relation to the Broad National Consumer Price Index (IPCA) (Barros, 2016). This situation raises two crucial questions: (a) why was the change in relative prices so small in the face of the substantial real increase in PWLI? and (b) how has this increase influenced the labor costs in the sector? 
The main objective of this study is to answer to these questions, focusing on Brazilian agrobusiness and its segments. For this, we applied the procedure developed by Barros (2016) and used by the author to assess the issue for the Brazilian economy as a whole.

For the period from 2002 to 2012, Barros (2016) analyzed the strong real growth of PWLI compared to the IPCA in the Brazilian labor market based on three variables, real unit labor costs (CURT) borne by employers; labor productivity; and the ratio between the IPCA (price index relevant to wage earners when valuing their remuneration) and the GDP deflator (price index relevant to employers when calculating production costs). The author found that from 2005 through 2011 the significant increase in real PWLI occurred without pressure and, in most cases, followed by reductions in the CURT. This dynamic is very favorable for both worker and employer, and it was made possible because, on the one hand, the GDP deflator rose more rapidly than IPCA and, on the other, labor productivity increased (Barros, 2016). In other situations, increases in PWLI, unless accompanied by increases in labor productivity, would raise production costs, and then reduce employment levels. According to Barros (2016), if it were not for the de-coupling between the IPCA and the GDP deflator, the rather slow labor productivity growth would have made the observed real wage advances unviable.

It is important to verify whether this conclusion holds specifically for the agrobusiness sector, which have been performing better than the remaining economic sectors both domestically and externally. Agrobusiness has accounted for about 20\% of national GDP over the 1996 to 2016 period and for about 20\% of the total employed population in the country from 2012 to 2020 (Centro de Estudos Avançados em Economia Aplicada, 2017), in spite of a reduction of between $20 \%$ to $25 \%$ in its relative price (Barros et al., 2020) The competitiveness of agrobusiness is also evidenced by fact that, for Brazil as a whole, the ratio of exports to GDP has grown from $6.1 \%$ to $12.9 \%$ from 1995 to 2018 , while, for agrobusiness specifically the evolution was from $7.4 . \%$ to $25.9 \%$ (Barros \& Castro, 2020).

As for the labor market, the average real PWLI grew in agrobusiness more rapidly than in the whole economy, 3.81\% compared to 3.35\% per year between 2004 and 2015 according to data from the National Household Sample Survey (Pesquisa Nacional por Amostra de Domicílios [PNAD], 2017d). The rise in real wages in Brazil have been pulled to a degree by the government policy of raising official minimum wage, which, from 1995 to 2019, increased at the average rate of 3.72\% per year (Instituto de Pesquisa Econômica Aplicada, 2020).

In order to apply the Barros (2016) procedure to Brazilian agrobusiness and its segments, and then explore the relationship between labor cost and PWLI in the sector, it was necessary to first build the labor productivity series, which were not available with the desired segmentation. We calculated a single factor productivity measure relating employment with value-added (VA) - measured by hours worked and GDP, respectively - , showing how productive work is used to generate value added over time. To estimate the total hours worked in agrobusiness and its segments we used mainly microdata from the annual PNAD and adaptations of the procedures from Castro et al. (2017, 2020). The analysis period, 2004 to 2015, was selected considering the availability of the necessary secondary data.

Among the main results of the study, we found that productivity was the fundamental factor to prevent the strong real growth in labor income in agrobusiness from causing an increase in the CURT. Without the productivity growth, CURT would have increased at an annual rate of $3.7 \%$. And unlike what was observed for the Brazilian economy by Barros (2016), the gap between the sectoral deflator and the IPCA had a relatively small effect on this dynamic.

The contribution of the study is then related to the construction of indicators and the investigation of this puzzle about the interactions between PWLI, productivity and costs - also 
considering the deflator/IPCA ratio - with focus on agrobusiness, a sector of high economic and social relevance in Brazil.

\section{METHODS AND SOURCES OF DATA AND INFORMATION}

\subsection{Concepts of labor and agrobusiness}

In the following paragraphs, we sequentially detail the definition of employment adopted in this study; the definition of agrobusiness, which is the one used by Cepea in the calculation of the sector's GDP, and the adapted procedure used to distinguish people employed in agrobusiness from people employed in other sectors. The identification of people employed in agrobusiness is a necessary step for later calculation of labor productivity in the sector. For this identification, the main database used refers to the microdata from PNAD for the years 2004 through 2015 - except for 2010, year in which the survey was not carried out.

Due to methodological changes in PNAD survey, we chose 2004 as a starting point. In 2002, PNAD changed its activity classification categories to those used in the National Classification of Economic Activities-Domicile (Classificação Nacional de Atividades Econômicas-Domiciliar [CNAE-Domiciliar]). Prior to 2002, the survey used a different classification that had a low degree of sectoral detailing. In addition, data from the rural areas of Brazil's Northern region were first included in the PNAD survey in 2004, and we wanted to include these areas in the analysis-in 2015, $12.7 \%$ of the agricultural labor force was in the North.

In this research we adopt the employment definitions used in Instituto Brasileiro de Geografia e Estatística's (2015) PNAD: PNAD evaluates the employment based on individual information from the research reference week, the last full week of September; the people employed in the reference week are those who are ten years of age or older and (a) held a job paid for in the forms of either money, products, merchandise or other benefits; (b) were unpaid but worked for at least one hour a week to aid a household member who was self-employed, employer, or employee (in the production of primary goods), or a religious, charitable or cooperative institution;(c) worked to produce for self-consumption or in construction for their own use; and (d) were only temporarily not working during the reference period.

Regarding agrobusiness definition, Centro de Estudos Avançados em Economia Aplicada (2017) defines it as a set of chains with both upstream and downstream linkages to agricultural activities. For analytical purposes, CEPEA divides the sector into four contributing segments: inputs segment; primary segment (agriculture and livestock production, that is, farming); agroindustry segment (agricultural or livestock product processing); and agro-services (commerce, transportation, and others) segment. CEPEA's segmentation of the agrobusiness sector is adopted in this study. To calculate agrobusiness GDP, CEPEA computes the value added by activities according to the intensity of their linkage with the sector. To determine these intensities, CEPEA uses different proxies related to value added or production value.

In this study, to identify people employed in agrobusiness, we calculate annual coefficients to identify agrobusiness activities from the broadest CNAE-Domiciliar classifications available in PNAD. The coefficients of this study, whenever possible, are calculated using information related to labor market. The procedure for calculating these coefficients was adapted from Castro et al. $(2017,2020)$, which measured the agrobusiness labor market in 2014 for Minas Gerais and in 2017 for Brazil as a whole, respectively. In these two studies, the procedure for obtaining coefficients was created for the structure of activities of CNAE-Domicile 2.0, used by 
the Continuous version of PNAD and different from the classification adopted by the PNAD annual version (CNAE-Domiciliar).

Specifically, the number of individuals employed in agrobusiness is determined using PNAD microdata organized into CNAE-Domicile activity classifications. In some cases, the PNAD employment data assigned to a particular CNAE-Domiciliar classification can be immediately recognized as agrobusiness related employment and directly applied in our study. However, some broad CNAE-Domiciliar classifications group agrobusiness activities with non-agrobusiness activities in the same category. In these cases, to resolve the difficulty one can use data sources other than PNAD to estimate the percentage of individuals engaged in agrobusiness activities in the broad classification (Castro et al., 2017, 2020). Appendix 1 shows the definition of agrobusiness and activities for which obtaining the number of employed persons was direct and those for which it was necessary to use other sources of information.

For the activity categories that were not entirely related to agrobusiness, we used three different procedures to separate out the PNAD agrobusiness employees from others. First, to separate out the workers in the "Manufacture of Wearing Apparel" into agrobusiness and non-agrobusiness workers, we applied to the category total the coefficient of $0.36 \%$ calculated by CEPEA from data in the 2009 Brazilian National Accounts. No other possible disaggregation strategy was found in the literature.

Second, to measure the Agro-services segment employment, we calculated annual coefficients of linkage intensity for the retail, transportation and other services sectors using the annual input-output matrices from Guilhoto \& Sesso Filho $(2005,2010)$. The choice of activities partially linked to agrobusiness within the full range of service activities of the economy followed Centro de Estudos Avançados em Economia Aplicada (2017). Considering the official definition of the economy's Service sector, only the following service categories are considered not to be linked with agrobusiness: education; human health and social services; arts, culture, sport, and recreation; other activities and services; domestic services; and international organizations and other extraterritorial institutions.

It can be noted that, specifically in the two previous procedures, for the definition of the percent coefficients, information not related to the labor market was used. The third type of procedure was applied to all other activities besides the services and the Manufacture of Wearing Apparel, namely: Manufacture of Veterinary Medicines, Manufacture of Fertilizers and Pesticides and Manufacture of Agricultural Machinery and Equipment in the Inputs segment, and Manufacture of Natural-Based Textiles, Manufacture of Leather and Related Products and Leather Footwear and Manufacture of Wood Furniture in the Agroindustry.

The third type of procedure was based on information on the number of employees from the Annual Social Information Report (RAIS) database from the Brazilian Ministry of Labor and Employment (MTE) to calculate the disaggregation percent coefficients that vary annually. The RAIS database was used because it is the only Brazilian labor force-oriented survey that separates data into CNAE 2.0 categories - the most detailed disaggregation available (Castro et al., 2020). The RAIS database includes only formally employed workers. That said, as discussed in Castro et al. (2020), the hypothesis behind the use of these coefficients is that the distribution of all employed persons within an activity among its subcategories is the same as that of formal jobs among these subcategories.

Appendix 2 presents the historical series of the percent coefficients used in each agrobusiness activity and details on the specific data sources and specific procedures for each one. As an example, using formal employment data from RAIS, it was found that, in 2015, 9\% of the formal jobs in the Manufacture of Pharmaceutical Products industry were specifically in the agrobusiness activity Manufacture of Veterinary Medicines; then, the $9 \%$ coefficient was applied to the total number of people employed in the PNAD's Manufacture of Pharmaceutical Products industry 
to obtain the estimated total number of people employed in the Manufacture of Veterinary Medicines in 2015.

A summary of the procedures used to estimate the number of employees in those activities not completely allocated to agrobusiness is as follows: (a) the percent coefficients used in the Agro-services segment were calculated annually, following the definitions of Centro de Estudos Avançados em Economia Aplicada (2017) and using data from the input-output matrices from Guilhoto \& Sesso Filho $(2005,2010)$; (b) the coefficient used for Manufacture of Wearing Apparel was kept fixed every year and obtained directly from Centro de Estudos Avançados em Economia Aplicada (2017); (c) all other coefficients were calculated annually, following the definitions of Castro et al. $(2017,2020)$ and using RAIS formal employment data.

\subsection{Labor productivity series}

In this research, we calculate a single factor productivity measure that relates labor use with value added (VA). This measure of productivity only partially reflects labor factor productivity in terms of the worker's personal capacities and intensity of effort; rather, it depends largely on the combined influence of other inputs, such as changes in capital, technology, organizational system and efficiency, and is affected by measurement errors and economies of scale (Organization for Economic Co-Operation and Development, 2010). The labor productivity indicator does not distinguish gains related to the use of new techniques or technologies from the ones related to the substitution of capital for labor. Therefore, variations in labor productivity must be interpreted cautiously (Ellery Junior, 2014).

Cavalcante \& De Negri (2014) analyzed the dynamics of several labor productivity indicators in Brazil and systematized the results obtained by previous analyses. Options 1) to 4) summarize what the authors found to be the most frequently used indicators when analyzing labor productivity in Brazil: 1) Aggregate measures that relate GDP to the total employed population using IBGE data; 2) For sector analysis, the quotient between VA and total employed population calculated using data generally obtained from the national accounts; 3) The quotient between the value of industrial transformation (VTI) or VA and employed population with data from the IBGE Annual Survey of Industry (PIA) and the IBGE Annual Survey of Services (PAS). In these cases, the industrial and service sectors are emphasized; 4) The quotient between production and hours worked with data gathered from the IBGE Monthly Survey of Industry-Physical Production (PIM-PF) and the IBGE Monthly Survey of Industrial Employment and Wages (PIMES).

The authors point out that hours worked is a better indicator than employed population and that VA is a better indicator than production quantity when analyzing labor productivity. In periods when the relation between production value and intermediate consumption is changing, the production quantity as measure of productivity becomes less precise (Cavalcante \& De Negri, 2014). Barbosa Filho \& Pessôa (2014) calculated Brazilian labor productivity for the years from 1982 to 2012. They consider hours worked rather than employed persons, but still consider GDP as the measure of output - solving the limitation present in approach number 4. During the 1980s and 1990s, house worked varied significantly. After the year 2000, working time fluctuated much less. In this research, we chose to consider the working time because there is no previous knowledge about the dynamics of this variable for agrobusiness in the analyzed period.

Considering the pros and cons of different approaches and the data availability, we estimate labor productivity for agrobusiness and its segments using the quotient between value added, measured by GDP, and hours worked by the employed population. Value added is a more accurate measure than output (Cavalcante \& De Negri, 2014); and the use of hours worked is 
intended to eliminate bias related to variations in working time (Barbosa Filho \& Pessôa, 2014; Cavalcante \& De Negri, 2014).

Therefore, first, we calculate the total hours worked in agrobusiness, its segments and the entire economy. The total hours worked in the month of September each year (Hours ${ }_{j, t}$ ) is obtained by adding up the total hours worked of all remunerated and unpaid employee individuals and expanding them by each observation's IBGE assigned weight in the working population according to (1):

$$
\text { Hours }_{j, t}=\sum_{i=1}^{N j} p_{i t} H T_{i t}
$$

where $t$ represents the years from 2004 to 2015 other than 2010, $i$ refers to the individuals in the sample (sample size $M), p_{i t}$ are the individuals weights, $H T_{i t}$ are the total hours worked by the individual in the month of September of the year $t$, and $j$ are the different groups for which the series are calculated ( $j$ = agrobusiness, inputs, primary, agroindustry, agro-service and Brazil). Based on the total hours worked, we calculate labor productivity according to (2):

$P T_{j, t}=G D P_{j, t} /$ Hours $_{j, t}$

Brazilian GDP data came from Instituto Brasileiro de Geografia e Estatística's (2017a) National Accounts and agrobusiness and agrobusiness segments GDP data came from CEPEA.

\subsection{The determinants of the aggregate dynamics of labor income at the sectoral level}

This section presents the procedure for analyzing the determinants of the aggregate dynamics of PWLI, based on Barros (2016). Trends in three different variables can explain the dynamics of PWLI, real unit labor costs (CURT), the costs borne by employers; labor productivity (PT); and relative behavior of the IPCA against the GDP deflator (Barros, 2016). The unit labor cost (CUT) is the ratio between PWLI and labor productivity (PT, with $P T_{j, t}=G D P_{j, t} /$ Hours $_{j, t}$ ). CUT will increase if PWLI increases more than productivity and fall if productivity increases exceed wage increases (Mello \& Barbosa-Filho, 2014). For the sectors $j$, CUT can be expressed by (3):

$$
C U T_{j, t}=\frac{P W L I_{j, t}}{\left(\frac{G D P_{j, t}}{\text { Hours }_{j, t}}\right)}
$$

The ratio of CUT to the GDP deflator (DEF) of sector $j$ generates CURT, the real unit labor cost (4):

$$
\operatorname{CURT}_{j, t}=\frac{P W L I_{j, t}}{D E F_{j, t}} \cdot \frac{\text { Hours }_{j, t}}{G D P_{j, t}}=\frac{P W L I_{j, t}}{D E F_{j, t}} \cdot \frac{1}{P T_{j, t}}
$$

with GDP expressed as a volume indicator. Barros (2016) also includes the relation with the consumer deflator (IPCA) in (4), so that we have (5):

$C U R T_{j, t}=\frac{P W L I_{j, t}}{I P C A_{t}} \cdot \frac{\text { Hours }_{j, t}}{G D P_{j, t}} \cdot \frac{I P C A_{t}}{D E F_{j, t}}$

From (5) it is possible to analyze the movements of real PWLI ( $\left.\frac{P W L I_{j, t}}{I P C A_{t}}\right)$ explained by CURT, productivity, and the ratio between the deflator's variations (6):

$\ln \left(\frac{P W L I_{j, t}}{I P C A_{t}}\right)=\ln (C U R T)+\ln \left(\frac{G D P_{j, t}}{\text { Hours }_{j, t}}\right)+\ln \left(\frac{D E F_{j, t}}{I P C A_{t}}\right)$ 
This decomposition of the dynamics of real PWLI is used in our study. We found a similar procedure in Mello \& Barbosa-Filho (2014), but their study did not consider the relation between the deflator and IPCA-CUT could vary due to changes in the average wage in the economy and/or average labor productivity. These authors assessed whether the relative loss of Brazil's competitiveness position vis-à-vis other countries is due to higher costs or reduced productivity and calculated the CUT for Brazil and its states. The authors emphasize that CUT is relevant only to relative analyzes, with its absolute level making little sense.

We calculated PWLI using PNAD predominantly (and the same procedures used to find employed population and hours worked); the Brazilian GDP deflator was obtained from IBGE National Accounts (Instituto Brasileiro de Geografia e Estatística, 2017a) and CEPEA made the GDP deflators for agrobusiness and its segments available. IPCA was obtained from the National System of Consumer Price Indexes by Instituto Brasileiro de Geografia e Estatística (2017b).

\section{RESULTS AND DISCUSSIONS}

\subsection{Employed population (EP), working time and labor income}

Table 1 presents the number of people employed in agrobusiness, its segments, and the total Brazilian economy annually from 2004 through 2015. In 2015, the agrobusiness labor force (24.39 million $^{1}$ ) accounted for $25.4 \%$ of the Brazilian EP. Of the agrobusiness labor force, almost half (12.8 million individuals) were employed in the sector's primary segment (farming). The remainder of the agrobusiness labor force was broken down as follows: the services segment accounted for about 29\% (6.9 million people); the agro-industrial segment for $18 \%$ (4.3 million), and the inputs segment for only $1 \%$ (230 thousand).

Table 1 - People employed in agrobusiness, its segments and the total economy (000s) and agrobusiness participation in total Brazilian employment - 2004 to $2015^{*}$

\begin{tabular}{ccccccc|}
\hline \multicolumn{7}{c}{ Employed People ('000) } \\
\hline Year & Inputs & Primary & Industry & Agro-services & Agrobusiness & Agrib. / Brazil \\
2004 & 230 & 17,395 & 4,509 & 5,924 & 28,058 & $33.0 \%$ \\
2005 & 209 & 17,433 & 4,800 & 5,779 & 28,221 & $32.2 \%$ \\
2006 & 200 & 17,086 & 4,847 & 5,857 & 27,990 & $31.0 \%$ \\
2007 & 243 & 15,997 & 4,867 & 5,838 & 26,944 & $29.8 \%$ \\
2008 & 186 & 15,609 & 5,067 & 6,128 & 26,989 & $29.0 \%$ \\
2009 & 249 & 15,143 & 4,837 & 6,350 & 26,579 & $28.5 \%$ \\
2011 & 216 & 14,159 & 4,560 & 6,350 & 25,284 & $26.9 \%$ \\
2012 & 204 & 13,263 & 4,790 & 6,617 & 24,873 & $26.1 \%$ \\
2013 & 231 & 13,443 & 4,717 & 6,971 & 25,363 & $26.1 \%$ \\
2014 & 234 & 13,934 & 4,653 & 7,191 & 26,012 & $26.0 \%$ \\
2015 & 230 & 12,804 & 4,349 & 6,955 & 24,338 & $25.4 \%$ \\
$2015 / 2004$ & $0.1 \%$ & $-26.4 \%$ & $-3.5 \%$ & $17.4 \%$ & $-13.3 \%$ & \\
\hline
\end{tabular}

Source: author' results, based on data from PNAD (Instituto Brasileiro de Geografia e Estatística, 2017d) and additional information from RAIS - MTE (Brasil, 2017), Centro de Estudos Avançados em Economia Aplicada (2017) and Guilhoto \& Sesso Filho (2005, 2010). *PNAD data unavailable for 2010.

1 These agrobusiness labor market numbers differ from those from Castro et al. (2020). Those authors used quarterly data provided in the PNAD-Continuous (PNAD-C) and the PNAD-C does not consider persons engaged in production for their own household consumption to be employed while the PNAD does. Over the years studied, there were between 3.5 and 4.5 million people employed for their own consumption. 
Employment in the agrobusiness inputs segment was relatively stable over the 2004 to 2015 study period while the sector's services segment saw a 17.4\% increase in employment, mainly from 2008. EP fell in both the agro-industrial and primary segments, especially in the latter. Therefore, the total EP in agrobusiness was 13.3\% less in 2015 than in 2004. Between those two years, the total EP in Brazil increased by $12.7 \%$ while the share of agrobusiness in the total EP decreased 7.6 p.p.

The EP in the primary segment shrank consistently over the period, falling $26.4 \%$. According to Maia \& Sakamoto (2014), the most significant changes in the primary segment EP occurred in the second half of the first decade of the 2000s, mainly a result of the significant reduction in EP in Brazil's Northeast region. The rural emptying in this region is associated with the infeasibility of small rural properties and the comparatively better opportunities in the urban areas (Maia \& Sakamoto, 2014; Buainain et al., 2013). Maia \& Sakamoto (2014) also highlight a significant EP reduction in Brazil's South region, probably due to the intensification and concentration of production to the detriment of small farms.

In the agro-industrial segment, employment increased between 2004 and 2008 and retreat thereafter. Analyzing RAIS data on formal employment, which allows for greater sectoral detailing, we verified that the increase in the number of employees in agroindustry up to 2008 was mainly related to the expansion of jobs in the livestock slaughtering, sugar and alcohol, and wearing apparel productions (Brasil, 2017). The decline in agro-industrial jobs from 2008 through 2015 observed in RAIS data was mainly due to the reductions in the textiles and clothing, footwear, and wooden products industries (Brasil, 2017). During this period, these subsegments' production also declined significantly. According to data from Instituto Brasileiro de Geografia e Estatística (2017c), between December 2008 and December 2015, textile production fell by $40 \%$, wearing apparel fell $25 \%$, leather preparation and leather goods production fell by $16 \%$, and the production of wooden products stagnated.

In addition to the reduction in EP, there was also a $4.8 \%$ reduction in the time those employed in agrobusiness spent working, of about 1.8 hours a week per employed person (Figure 1). In Brazil, the reduction of weekly working time was similar, 4.6\%. Therefore, labor productivity calculations that considered only the EP would underestimate productivity variations. Average working time for an employed person in farming fell by $8.2 \%$ (about 2.8 hours a week), much more than in other segments.
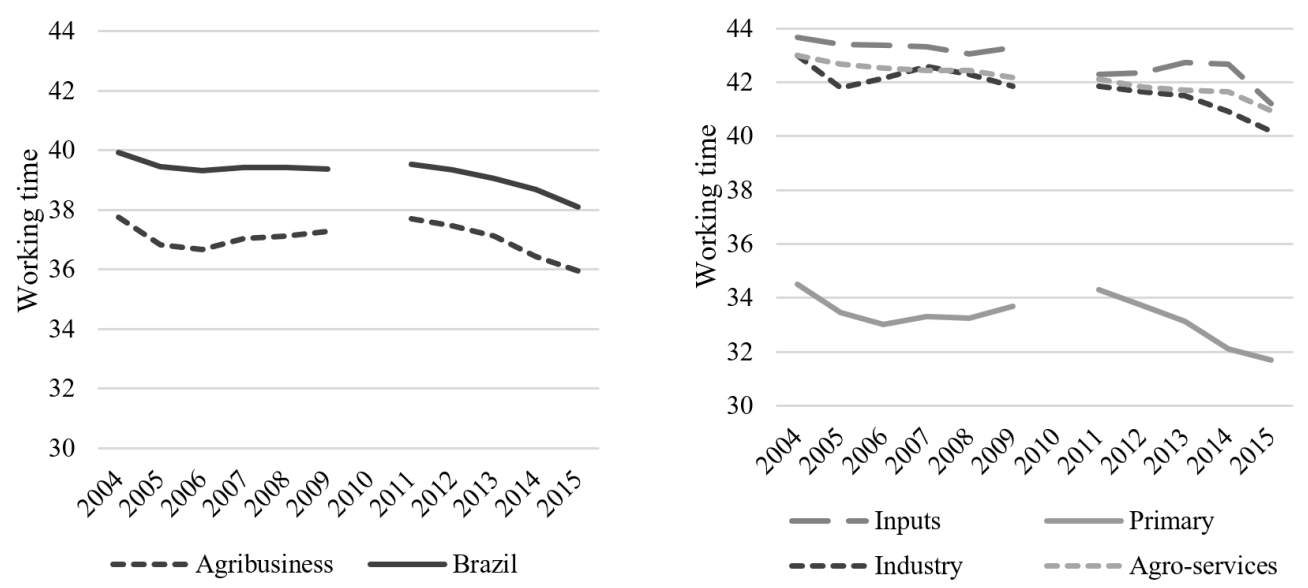

Figure 1 - Working time in Brazil and agrobusiness (left) and agrobusiness segments (right)*. Source: author' results, based on data from PNAD (Instituto Brasileiro de Geografia e Estatística, 2017d) and additional information from RAIS - MTE (Brasil, 2017), Centro de Estudos Avançados em Economia Aplicada (2017), Guilhoto \& Sesso Filho (2005, 2010). *PNAD data unavailable for 2010. 
Barbosa Filho \& Pessôa (2014) found that weekly hours of employment in Brazil fell from 40 to 39 between 2004 and 2012, following a trend that was stronger between 1982 and 1992-these results for Brazil are similar to those from our analysis².

Table 2 presents the average annual hourly PWLI for the entire Brazilian agrobusiness sector, its segments, and the entire economy. The average per worker hourly income level is much lower in agrobusiness when compared with the entire economy's average. In 2004, the average hourly income in agrobusiness, $R \$ 5.73$ in 2016 values (equivalent to the monthly amount of $\mathrm{R} \$ 865.00$ ), represented $73.92 \%$ of the average for the EP in the Brazilian economy. This difference slowly diminished over the analyzed period, with the average agrobusiness EP hourly incomes rising to $77.89 \%$ of the average in Brazil in 2015 (Table 2).

Table 2 - Average per worker hourly labor income (PWLI) usually earned in the main work, in $\mathrm{R} \$$ of $2016^{*}$, in Brazil, agrobusiness and its segments

\begin{tabular}{ccccccc} 
Year & Inputs & Primary & Industry & Agro-services & Agrobusiness & Brazil \\
2004 & 11.30 & 3.27 & 6.52 & 9.31 & 5.73 & 7.75 \\
2005 & 12.98 & 3.39 & 6.64 & 9.55 & 5.94 & 8.11 \\
2006 & 13.85 & 3.58 & 7.51 & 10.15 & 6.49 & 8.73 \\
2007 & 13.05 & 3.82 & 7.48 & 10.51 & 6.76 & 9.07 \\
2008 & 13.72 & 4.08 & 8.08 & 10.73 & 7.18 & 9.43 \\
2009 & 14.20 & 4.16 & 8.25 & 10.89 & 7.33 & 9.71 \\
2011 & 15.60 & 4.70 & 8.81 & 11.92 & 8.04 & 10.66 \\
2012 & 16.64 & 5.11 & 9.28 & 12.57 & 8.75 & 11.41 \\
2013 & 16.07 & 5.41 & 9.56 & 12.92 & 9.18 & 11.88 \\
2014 & 15.67 & 5.33 & 10.06 & 12.87 & 9.34 & 12.06 \\
2015 & 16.07 & 5.58 & 9.47 & 12.28 & 9.15 & 11.75 \\
$2015 / 2004$ & $42 \%$ & $70 \%$ & $45 \%$ & $32 \%$ & $60 \%$ & $52 \%$ \\
\hline
\end{tabular}

Source: author' results, based on data from PNAD (Instituto Brasileiro de Geografia e Estatística, 2017d) and additional information from RAIS - MTE (Brasil, 2017), Centro de Estudos Avançados em Economia Aplicada (2017), Guilhoto \& Sesso Filho $(2005,2010)$. *PNAD data unavailable for 2010 * $^{*}$ deflated by the IPCA.

The low average PWLI in agrobusiness reflects the unfavorable situation in the sector's primary segment (Table 2). In 2015, the average hourly PWLI in this segment was 58\% lower than the average in the economy. The agro-industrial segment also showed a lower hourly average income than that in the economy. The inputs and agro-services segments had the highest average agrobusiness PWLIs.

The unfavorable situation of those employed in the agrobusiness sector actually ameliorated over the period, mainly due to the real gain of $70 \%$ in hourly PWLI earned in the agriculture segment, higher than the average $52 \%$ gain in the rest of the economy. This segment's average real appreciation of PWLI relative to the IPCA was consistent from 2004 to 2013, interrupted only in 2014. Maia \& Sakamoto (2014) point out some factors that influenced the positive evolution of agriculture incomes between 1992 and 2012, increase in the mandatory minimum wage (the basis for payment of a relevant part of agricultural remuneration); an increase in the percentage of employees in total employment that were formally hired; agricultural productivity gains, especially in the South and Midwest regions (more intensive use of capital); and the pressure on wages stemming from the reduction of the rural Economically Active Population (EAP) partly due to migration to urban areas and the expansion of rural nonfarm work opportunities .

2 The average working day presented here is slightly shorter than that from Barbosa Filho \& Pessôa (2014) since these authors excluded unpaid workers who worked for less than 15 hours a week from their sample. In our study this exclusion was not necessary. 
Data in Table 2 also show that income gains were even more significant in agrobusiness, especially in the primary segment, than in the entire economy. A first step in understanding this issue is to know the behavior of productivity in the sector over the period studied, a topic to be addressed in the next subsection.

\subsection{Labor productivity}

As discussed earlier, during periods when working time fluctuates, calculating labor productivity by considering a hours-worked series is ideal. Figure 2 shows the comparison between the series of EP and hours-worked for agrobusiness and Brazil. During the 2004 to 2015 period, agrobusiness EP fell $13 \%$ and total hours worked fell by $17 \%$, due to the concomitant reduction of the working time. Over the same period, EP in the entire economy increased $13 \%$ and total hours worked increased $8 \%$.



Figure 2 - EP and total hours worked - agrobusiness and the total of the economy (Index number 2004 = 100). Source: author' results, based on data from PNAD (Instituto Brasileiro de Geografia e Estatística, 2017d) and additional information from RAIS - MTE (Brasil, 2017), Centro de Estudos Avançados em Economia Aplicada (2017), Guilhoto \& Sesso Filho (2005, 2010). *PNAD data unavailable for 2010.

For comparative purposes, Table 3 shows the dynamics over time of labor productivity indexes (2004=100) in agrobusiness and in Brazil based on two series, one calculated from EP data and one based on hours worked data (Hours). The Table also presents the results by Barbosa Filho \& Pessôa (2014) for Brazil. The slight difference between our series calculated for Brazil and that of Barbosa Filho \& Pessôa (2014) is related to the differences in the definition of EP.

Table 3 - Labor productivity (EP and hours worked) in agrobusiness and Brazil, and Brazilian labor productivity by Barbosa Filho \& Pessôa (2014) - Index number $2004=100^{* *}$

\begin{tabular}{cccccccc} 
& \multicolumn{3}{c}{ Productivity (EP) } & & \multicolumn{3}{c}{ Productivity (Hours) } \\
\cline { 2 - 3 } \cline { 6 - 7 } & Agrobusiness & Brazil & Brazil* & & Agrobusiness & Brazil & Brazil* $^{*}$ \\
2004 & 100.0 & 100.0 & 100.0 & & 100.0 & 100.0 & 100.0 \\
2006 & 99.2 & 100.2 & 100.6 & & 101.7 & 101.4 & 101.3 \\
2007 & 103.7 & 101.2 & 102.1 & & 106.7 & 102.7 & 103.1 \\
2008 & 110.9 & 107.0 & 106.3 & & 113.0 & 108.4 & 107.3 \\
\hline
\end{tabular}

Source: author' results, based on data from PNAD (Instituto Brasileiro de Geografia e Estatística, 2017d) and additional information from RAIS - MTE (Brasil, 2017), Centro de Estudos Avançados em Economia Aplicada (2017), Guilhoto \& Sesso Filho $(2005,2010)$ and National Accounts (Instituto Brasileiro de Geografia e Estatística, 2017a). *data from Barbosa Filho and Pessôa (2014); **PNAD data unavailable for 2010. 
Table 3 - Continued..

\begin{tabular}{|c|c|c|c|c|c|c|}
\hline & \multicolumn{3}{|c|}{ Productivity (EP) } & \multicolumn{3}{|c|}{ Productivity (Hours) } \\
\hline & Agrobusiness & Brazil & Brazil* & Agrobusiness & Brazil & Brazil* \\
\hline 2009 & 114.8 & 108.9 & 107.4 & 116.2 & 110.4 & 109.3 \\
\hline 2010 & & & 114.7 & & & 117.0 \\
\hline 2011 & 129.5 & 116.2 & 117.2 & 129.6 & 117.4 & 119.7 \\
\hline 2012 & 130.5 & 119.3 & 111.6 & 131.4 & 121.1 & 120.1 \\
\hline 2013 & 135.4 & 119.1 & - & 137.7 & 121.7 & - \\
\hline 2014 & 132.0 & 119.3 & - & 136.8 & 123.1 & - \\
\hline 2015 & 139.9 & 125.0 & - & 146.9 & 131.0 & - \\
\hline
\end{tabular}

Source: author' results, based on data from PNAD (Instituto Brasileiro de Geografia e Estatística, 2017d) and additional information from RAIS - MTE (Brasil, 2017), Centro de Estudos Avançados em Economia Aplicada (2017), Guilhoto \& Sesso Filho $(2005,2010)$ and National Accounts (Instituto Brasileiro de Geografia e Estatística, 2017a). *data from Barbosa Filho and Pessôa (2014); **PNAD data unavailable for 2010.

As expected, productivity growth would be underestimated if we only considered the EP rather than total hours worked. For agrobusiness, cumulative growth would be underestimated by 7p.p. The dynamics of Brazilian labor productivity in the period of our study was similar to that found by Barbosa Filho \& Pessôa (2014). According to these authors, productivity stagnated in the 1980s, grew slightly in the 1990s, and accelerated after 2004. The productivity dynamic was important for the growth of national GDP in the 2004 through 2015 period.

From the Table 3, it is also noted that agrobusiness productivity grew more than the country's average in every year except for 2012 and 2014. As a result, agrobusiness productivity growth exceeded the Brazilian average by 16p.p. over the period.

Results in Table 3 indicate, according to our estimates, that the average annual growth rate was as follows. For productivity based on EP, 3.1\% for agrobusiness and 2.05\% for Brazil. For productivity based on hours worked, 3.56\% for agrobusiness and 2.49\% for Brazil. Considering the estimates by Barbosa Filho and Pessôa, the rates were 1.38\% using EP and 2.31\% using hours worked. Cavalcante \& De Negri \& (2014) found that the average rate of annual growth of Brazilian labor productivity (GDP/EP) was 1.09\% between 1992 and 2001, and 1.17\% between 2001 and 2009. They point out that there are different methods of adjusting the employment series and varying the time period aggregations, both of which can lead to different results. Bonelli \& Bacha (2011) found that the average rate of annual growth of Brazilian labor productivity was 0.36\% between 1993 and 1999, rising to 0.67\% for the period between 2000 and 2009; Bonelli \& Veloso (2012) found that the average annual rate of labor productivity growth was $1.2 \%$ over the 2003 to 2009 period; Squeff (2012) concluded that between 2000 and 2009, average annual productivity growth was $1 \%$.

Table 4 shows the agrobusiness segments' productivity. Productivity in the primary segment grew $121.8 \%$ over the period, an annual average growth rate of 7,24\%, with consistent year-onyear growth. Productivity gains were a result of the combined movement of the segment's GDP growth and reduced hours worked. Gasques et al. (2012a) found that the Brazilian agricultural production index increased by 30.3\% between 2004 and 2011, while the input index, which includes land, labor, and capital, fell by $17.9 \%$. The input index's decrease reflects reductions of $12.7 \%$ and $6.2 \%$ in the labor and land indexes, respectively, and relative stability in the capital index $(+0.3 \%)$. That is, the increase in production during this period occurred concurrently with a reduction of land and labor use and increases in the capital/land and capital/labor ratios. Since capital encompasses tractors, fertilizers and pesticides, the results suggest that an intensification of technology usage was associated with PTF increases. 
Table 4 - Labor productivity - Productivity (Hours) - in agrobusiness and its segments Index number $2004=100$

\begin{tabular}{cccccc}
\multicolumn{5}{c}{ Productivity (Hours) } \\
\cline { 2 - 6 } & Inputs & Primary & Agroindustry & Agro-services & Agrobusiness \\
2004 & 100.0 & 100.0 & 100.0 & 100.0 & 100.0 \\
2005 & 97.3 & 101.0 & 98.4 & 103.8 & 101.7 \\
2006 & 100.5 & 113.4 & 99.2 & 105.6 & 106.7 \\
2007 & 96.6 & 120.5 & 101.0 & 109.2 & 113.0 \\
2008 & 137.2 & 134.4 & 98.4 & 106.6 & 116.5 \\
2009 & 97.5 & 141.0 & 101.5 & 101.0 & 116.2 \\
2010 & & & & & \\
2011 & 134.3 & 158.1 & 114.9 & 108.1 & 129.6 \\
2012 & 145.4 & 165.2 & 110.2 & 104.5 & 131.4 \\
2013 & 135.7 & 187.2 & 113.6 & 104.3 & 137.7 \\
2014 & 133.5 & 188.9 & 115.8 & 100.9 & 136.8 \\
2015 & 131.4 & 221.8 & 121.0 & 104.0 & 146.9 \\
\hline
\end{tabular}

Source: author' results, based on data from PNAD (Instituto Brasileiro de Geografia e Estatística, 2017d) and additional information from RAIS - MTE (Brasil, 2017), Centro de Estudos Avançados em Economia Aplicada (2017), Guilhoto \& Sesso Filho $(2005,2010)$ and National Accounts (Instituto Brasileiro de Geografia e Estatística, 2017a). *PNAD data unavailable for 2010 .

Studies that address labor productivity in the agricultural sector in Brazil are less frequent. The sector was addressed by Carvalheiro (2003) as part of a sectoral analysis of labor productivity during the 1990s. He used the national accounts to provide both VA and EP data for Brazil's economic sectors. The study's results for labor productivity growth in the agriculture sector were $+8.73 \%$ between 1990 and $1994 ;+24.58 \%$ between 1994 and 1998 and $+8.99 \%$ between 1998 and 2000 , or $47.63 \%$ over the full period. Labor productivity growth in the country's entire economy was $11.96 \%$.

Squeff (2012) used the ratio between VA (corrected by the respective sector deflators to eliminate the price effect) and EP and found that labor productivity in agriculture grew at an average annual rate of $4.5 \%$ between 1995 and 2009 while the average labor productivity growth rate for the entire Brazilian economy was $0.8 \%$. The author states that this growth in agriculture took place with a large increase in VA (63.2\%) and a negative variation in total EP $(-12.2 \%)$. Squeff's calculations (2012) disregard the working time.

Freitas (2014) summarized agricultural productivity results from previous research focused on Brazil. The author noted that TPF measures were used by the great majority of these studies, among them those by Barros (1999), Gasques et al. (2012a, 2012b) and Fuglie et al. (2012). Barros (1999) determined that the Brazil's agricultural product grew 3.26\% annually between 1975 and 1995 , with land productivity increasing by $2.47 \%$ and labor productivity by $3.26 \%$. Brigatte \& Teixeira (2011) found that agricultural TFP grew $0.47 \%$ annually between 1974 and 2005, and Gasques et al. (2012b) found that between 1995 and 2006, 68\% of agricultural product growth was due to productivity gains. Although labor productivity in agriculture has grown faster than in other economic sectors, it should be noted, as highlighted by Veloso et al. (2017), that it still has a low value in relation to the productivity of the industrial and service sectors and also compared to agricultural productivity in developed countries.

Overall, agricultural labor market was characterized by EP reduction and increases in PWLI and productivity - movements related to each other and with a generally higher intensity than those observed in the other segments and in Brazil. Rezende (2006) discusses the reasons that led Brazilian agriculture to adopt this technological standard, of mechanization to replace the less 
qualified labor force typically found in agriculture (and abundant in Brazil) by the intensive use of capital and qualified work (factors that are scarce in the economy). This author points out that this process began in the 1960s and that, in face of a distortion of the production factors' relative prices caused by land, labor and credit policies, there was excessive mechanization in agriculture.

Agro-services labor productivity fluctuated over the entire study period, increasing from 2004 to 2007, in 2011, and 2015, while declining in 2008 and 2009 and from 2012 to 2014. According to Arbache (2015), the service sector's productivity is quite low and variable. Jacinto \& Ribeiro (2015) point out that Brazilian productivity studies emphasize the industrial sector, with few researchers directing their attention to the service sector.

Accumulated agro-industrial labor productivity growth was 10p.p. below that of the economy over the study period. Productivity in this segment stagnated between 2004 and 2009. Squeff (2012) pointed out that processing industry productivity had the worst performance of the economic sectors between 2000 and 2009, registering a negative annual average growth of $0.8 \%$. Cavalcante \& De Negri (2014) also analyzed the productivity of the industrial sector from 1996 to 2011 (VTI / EP) and found a downward trend between 2000 and 2011.

Galeano \& Feijó (2013) found that the average change rate of Brazilian industry labor productivity between 1996 and 2007 was $-0.62 \%$. The authors also calculated labor productivity growth by sector and for some agrobusiness-related industries that they considered low-tech. For these industries, the results pointed to productivity growth in the manufacture of tobacco products $(68.26 \%)$, of wearing apparel $(77.95 \%)$, of wood products $(17.36 \%)$ and of cellulose, paper and paper products $(10.69 \%)$. On the other hand, they found that productivity decreased for food products and beverages $(-17.8 \%)$, textiles $(-5.42 \%)$, leather and footwear $(-3.32 \%)$, furniture and other industries $(-0.12 \%)$.

From the results already presented, it is possible to perform a decomposition of GDP growth broken down into labor productivity growth based on the employed population-Productivity (EP) - and the actual growth of the EP. In turn, Productivity (EP) can be decomposed into labor productivity based on the hours worked-Productivity (hours) - and the annual average working time (Barbosa Filho \& Pessôa, 2014)3. Table 5 presents these results for Brazil, agrobusiness, and the agrobusiness segments from 2004 through 2015.

Table 5 - Decomposition of GDP growth for Brazil, agrobusiness, and agrobusiness segments, 2004 thru 2015 (annual \%)

\begin{tabular}{|c|c|c|c|c|c|}
\hline & \multirow[b]{2}{*}{ GDP } & \multicolumn{3}{|c|}{ Productivity (EP) } & \multirow[b]{2}{*}{ EP } \\
\hline & & $\begin{array}{l}\text { Productivity } \\
\text { (hours) }\end{array}$ & $\begin{array}{l}\text { Working } \\
\text { time }\end{array}$ & Total & \\
\hline Inputs & $1.96 \%$ & $2.48 \%$ & $-0.53 \%$ & $1.96 \%$ & $0.01 \%$ \\
\hline Primary & $3.68 \%$ & $7.24 \%$ & $-0.78 \%$ & $6.46 \%$ & $-2.79 \%$ \\
\hline Agroindustry & $0.79 \%$ & $1.73 \%$ & $-0.61 \%$ & $1.12 \%$ & $-0.33 \%$ \\
\hline Agro-services & $1.37 \%$ & $0.35 \%$ & $-0.44 \%$ & $-0.09 \%$ & $1.46 \%$ \\
\hline Agrobusiness & $1.76 \%$ & $3.50 \%$ & $-0.44 \%$ & $3.06 \%$ & $-1.29 \%$ \\
\hline Brazil & $3.12 \%$ & $2.46 \%$ & $-0.42 \%$ & $2.03 \%$ & $1.09 \%$ \\
\hline
\end{tabular}

Source: author' results, based on data from PNAD (IBGE, 2017d) and additional information from RAIS - MTE (Brasil, 2017), Centro de Estudos Avançados em Economia Aplicada (2017), Guilhoto \& Sesso Filho $(2005,2010)$ and National Accounts (Instituto Brasileiro de Geografia e Estatística, 2017a). *PNAD data unavailable for 2010.

${ }^{3}$ Adapted from Barbosa Filho \& Pessôa (2014):

$$
\frac{1}{N} \ln \left(\frac{G D P_{(t+N)}}{G D P_{t}}\right)=\frac{1}{N} \ln \left(\frac{\text { Prod_hours }_{(t+N)}}{\text { Prod_hours }_{t}}\right)+\frac{1}{N} \ln \left(\frac{\text { Working time }_{(t+N)}}{\text { Working time }_{t}}\right)+\frac{1}{N} \ln \left(\frac{E P_{(t+N)}}{E P_{t}}\right)
$$


Between 2004 and 2015, Brazilian agrobusiness GDP grew at an annual rate of 1.76\%. This growth can be attributed -focusing on the labor factor - to hourly productivity gains of 3.5\% reduced by a fall in average working time (-0.44\%) and a decline in the agrobusiness EP (-1.29\%).

As expected, the dynamics observed in agrobusiness are milder but similar to the dynamics of the sector's primary segment. This segment's GDP annual growth of $3.68 \%$ was a response to an hourly productivity increase of 7.24\%; however, this growth was softened by relatively high reductions in both EP (-2.79\% annually) and working time (-0.78\% annually). A similar milder scenario was verified for the agro-industrial segment. In the input segment, the number of EP was stable over the analyzed period while the hourly productivity increased and working time reduced to a lesser extent resulting in a segment GDP growth. In the agro-services segment, in contrast, an increase in EP accounted for most of the segment's GDP growth, with a modest average gain in hourly productivity $(0.35 \%)$ being offset by a reduction in average working time (-0.44\%). For Brazil as a whole, labor productivity growth largely explains the growth of the GDP from 2004 to 2015. This result is close to the one obtained by Barbosa Filho \& Pessôa (2014) analyzing Brazil from 2002 through 2012.

\subsection{Determinants of the recent dynamics of agrobusiness labor income}

Figure 3 and Table 6 illustrate the components of real PWLI average annual growth rates in Brazil, agrobusiness, and agrobusiness segments, for the 2004-2015 period according to the Equation 5. The complete time series of the calculated indicators are also available in Appendix 3.

Table 6 - Components of real increase labor income in Brazil, agrobusiness and its segments comparison between 2015 and 2004 (in \% per year).

\begin{tabular}{lcccccc} 
& Inputs & Primary & Agroindustry & Agro-service & Agrobusiness & Brazil \\
PWLI/IPCA & 2.67 & 4.07 & 2.77 & 2.08 & 3.81 & 3.35 \\
CURT & 1.26 & -2.56 & 0.85 & 1.10 & 0.21 & -0.81 \\
Productivity & 2.48 & 7.24 & 1.73 & 0.35 & 3.50 & 2.46 \\
Def/IPCA & -1.07 & -0.61 & 0.20 & 0.62 & 0.10 & 1.71 \\
\hline
\end{tabular}

Source: author' results, based on data from PNAD (Instituto Brasileiro de Geografia e Estatística, 2017d) and additional information from RAIS - MTE (Brasil, 2017), Centro de Estudos Avançados em Economia Aplicada (2017), Guilhoto \& Sesso Filho (2005, 2010), National Accounts (Instituto Brasileiro de Geografia e Estatística, 2017a), National System of Consumer Price Indexes (Instituto Brasileiro de Geografia e Estatística, 2017b).



Figure 3 - Components of real increase labor income in Brazil, agrobusiness and its segments comparison between 2015 and 2004 (in \% per year). Source: author' results, based on data from PNAD (Instituto Brasileiro de Geografia e Estatística, 2017d) and additional information from RAIS - MTE (Brasil, 2017), Centro de Estudos Avançados em Economia Aplicada (2017), Guilhoto \& Sesso Filho (2005, 2010), National Accounts (Instituto Brasileiro de Geografia e Estatística, 2017a) and Instituto Brasileiro de Geografia e Estatística (2017b). 
Analyzing Brazil between 2002 and 2012, Barros (2016) verified the relevant role of the gap between the GDP deflator and IPCA and of the productivity to allow the real increase in PWLI without equivalent pressure on employer costs - and employment level. If in the period under study the deflator and the IPCA had increased by the same magnitude, the real income increase of $35.4 \%$ would have been accompanied by a $10 \%$ increase in CURT, but CURT actually shrank by $8 \%$ over the period (Barros, 2016).

From Figure 3 and Table 6, we see that the average annual PWLI growth of 3.35\% relative to the IPCA in the Brazilian economy was accompanied by an annual CURT reduction of $0.81 \%$. The average annual growth of $2.46 \%$ in productivity and of $1.71 \%$ in the DEF/IPCA indicator (or faster deflator growth than IPCA growth) enabled this result. Over the same period, if the deflator and the IPCA had grown by the same magnitude, CURT could have grown $0.9 \%$ per year; and, if, instead, productivity had not grown, CURT would have grown $1.6 \%$ per year.

The agrobusiness results are quite different from those for Brazil. First, in general, the DEF/IPCA relation did not play a preponderant role - it played a negative role in the input and primary segments since IPCA increased at higher rates than the segments' deflators. In fact, there was a fall in relative prices for all agrobusiness segments, especially the primary and input segments, when compared to the total economy over the analyzed period. This can be seen in Figure 4.

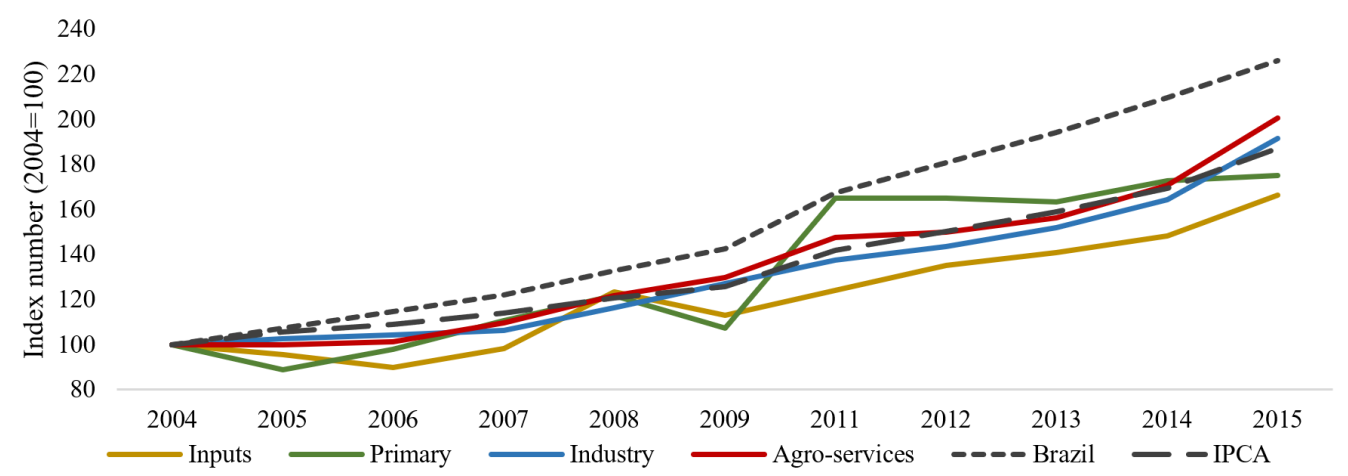

Figure 4 - Index numbers of the deflators of the national GDP (Brazil) and agrobusiness' segments' GDP, and IPCA, between 2004 and 2015. Source: author's results based on National Accounts/IBGE (Instituto Brasileiro de Geografia e Estatística, 2017a), National System of Consumer Price Indexes/IBGE (Instituto Brasileiro de Geografia e Estatística, 2017b), Centro de Estudos Avançados em Economia Aplicada (2017).

Barros (2016) found that international commodity dollar prices grew $9.8 \%$ annually between 2003 and 2011; however, with the Brazilian currency's strong appreciation relative to the USD, domestic commodity prices grew only $4 \%$ a year. With the growth of exports, mainly agrobusiness products, sector exporters transferred income to importers, so that the IPCA grew less than the economy's deflator (Barros, 2016). A comparison of the economy's deflator and the agricultural deflator shows that relative agricultural product prices fell over the period, even though the sector deflator appreciated over the IPCA. An in-depth discussion of the relation between IPCA and GDP deflator can also be found in Silva et al. (2017). The authors show that this relation seems to depend on the exchange rate and the output gap. Specifically, they find that the higher the exchange rate and the greater the capacity utilization rate, the higher the GDP deflator/IPCA ratio.

In the primary segment, the DEF/IPCA ratio's fall of $0.61 \%$ annually had relatively little effect on CURT, which was significantly reduced by productivity growth of $7.24 \%$ a year. Even with a $4.07 \%$ annual average real PWLI increase, this productivity growth led to a $2.56 \%$ yearly CURT 
decrease (Figure 3 and Table 6). Without the significant productivity growth in this segment, the income increase would have pushed CURT up, annually increasing it by $4.7 \%$. The successive increases in CURT, in turn, could lead to an increase in unemployment in the sector, with the intensification of the technological advance process aimed at the replacement of labor.

In the input segment, productivity gains of $2.48 \%$ a year were not sufficient to offset the annual $1.07 \%$ decline in the ratio DEF/IPCA. As a result, the annual real increase in PWLI of $2.67 \%$ (over the IPCA) was reflected in a CURT increase of $1.26 \%$ a year. Without the productivity growth, the increase in labor income would have led to an annual 3.7\% increase in CURT. In the agroindustry segment, the real annual increase of $2.77 \%$ in PWLI was not fully reflected in CURT because labor productivity grew by $1.73 \%$ a year. However, since the ratio DEF/IPCA for this segment had little effect on the observed dynamics, CURT still grew at $0.85 \%$ a year. Analogously to the other segments, without the productivity gains, CURT would have grown $2.6 \%$ per year.

According to Pastore et al. (2012), the increase in the unit labor cost affects the processing industry in general leading to a reduction in the use of installed capacity and production relative to its trends. In addition, as the industry is open to international trade, unlike the services sector, it is largely a price taker. In this way, the transfer of the labor cost increase to prices is restricted, leading to margin reduction, discouraging production, and probably affecting employment level. In the recent past, even with the reduction of the interest rates as a reaction to the 2008 economic crisis, the rise in wages and the stagnation of labor productivity, with a consequent increase in unit labor costs, led to a fall in capacity utilization by Brazilian industry (Pastore et al., 2012).

In the agro-services segment, change in productivity had the least influence on the observed change in CURT. The effect of real PWLI gains (2.08\% per year), slightly softened by the minimal de-coupling between this segment's deflator and IPCA (+ $0.62 \%$ per year), caused an average annual $1.1 \%$ increase in CURT over the study period.

According to Pastore et al. (2012), in response to the 2008 crisis, Brazilian government acted aiming at stimulating aggregate demand. The resulting expansion of the service sector's demand then raised the demand for labor and was responsible for the drop in unemployment and the growth of real wages. As the services sector, as well as agro-services, are generally closed to international trade, the increase in costs resulting from the increase in the unit labor cost can more easily be passed on to prices, with a magnitude depending on the price elasticity of demand (Pastore et al., 2012) and on the current point in the economic cycle. During recessions, for example, the pass-through of costs to prices tends to be lower than in other conditions. Between 2008 and 2015, while prices of tradable products increased by 55.7\%, non-tradable products, especially in the service sector, increased by $80.7 \%$ (Banco Central do Brasil, 2018).

Another important point is related to the fact that in the Brazilian services sector productivity traditionally grows quite slowly (Veloso et al., 2017). Therefore, increases in wages must raise in greater magnitude the unit labor cost. Since this sector has historically been very labor intensive, there has been both a technological limit to labor substitution and great difficulty transmitting cost increases specially in recession periods 4 . Additionally, service sector dynamics directly and indirectly affect employment and income generation in the other economic sectors. As the service sector is the major Brazilian employer (Pastore at al., 2012), and services represent an important direct cost for companies in general, especially those in the manufacturing industry (Arbache, 2015), wage increases in this sector should raise salaries and, thus, costs in other sectors.

\footnotetext{
${ }^{4}$ A word of caution is necessary at this point: recently important technology changes related to the Internet, Information Technology (IT) and Automation have been taking place with impacts on the capital/labor relation and, therefore, on jobs maintenance and creation. Services activities have not been exceptions. The Covid-19 pandemic added to the potential jobs scenario changes resulting from new technology adoption. The impacts of these supply and demand severe shocks are still to be evaluated.
} 
Real average annual PWLI gains of 3.81\% in the aggregated agrobusiness had little overall impact on CURT, which only increased $+0.21 \%$ annually over the 2004-2015 period, mainly due to sectoral productivity gains of $+3.5 \%$. Without this productivity growth, notably in the primary and also in the agro-industrial segments, CURT would have increased at an annual rate of $3.7 \%$.

\section{CONCLUSIONS}

The agrobusiness labor force decreased by 13.3\% over the 2004 through 2015 period. This reduction was mainly driven by job losses in the primary segment, but there also was a decline in the agro-industrial labor force, especially after 2008. On the other hand, employment in agroservices segment increased, more intensively after 2008. The average time spent working in the primary segment decreased more than in the other agrobusiness segments and in Brazil as a whole over the period. In agrobusiness sector, the reduction in average working time was similar to that in the other Brazilian economic sectors. Over the same period, while employment and working time decreased in the agrobusiness sector, average real PWLI increased, mainly driven by real PWLI gains in the primary segment. From 2004 through 2015, PWLI increased by $56 \%$ in the primary segment, by $52 \%$ in agrobusiness and by $45 \%$ in the Brazilian economy.

The results of the study demonstrate that the scenario for agrobusiness in the face of this increase in labor income was quite different from what the literature had already observed for Brazil. Although the annual average increase in agrobusiness sector PWLI (+3.81\%) was even higher than those in the whole economy, our findings show that agrobusiness CURT only rose $0.21 \%$ over the period. The CURT increase that would be expected to coincide with higher PWLIs was almost entirely offset by increased labor productivity (+3.5\%), especially in the primary segment, combined with a slightly favorable relationship between the sector's deflator and the IPCA.

Therefore, in the future - in fact, at any time - increases in labor income over the IPCA will raise CURT, unless income increases are offset by continued productivity growth or by significant detachments between the IPCA and deflators.

The agro-industrial agrobusiness segment has always faced problems when attempting to increase competitiveness and productivity, making increased labor costs a disincentive to production and employment. In the agro-services segment, like in the general services sector of the economy, productivity traditionally grows quite slowly; therefore, increases in wages must raise in greater magnitude the unit labor cost. Since the service sector predominantly produces non-tradable goods, the transmission of potential labor cost increases to prices is facilitated; however, since this sector is very labor intensive, there is both a technological limit to labor substitution and great difficulty transmitting cost increases to prices particularly when the economy is in recession and demand is weak.

As for the primary segment of agrobusiness, on the contrary, productivity growth has been and should remain consistent, which, in principle, could offset the effects of increases in PWLI on CURT. However, there may be a long-term cost from the worker's perspective, if increases in labor income leads to substitution of capital for labor and to intensify mechanization and automation.

\section{REFERENCES}

Arbache, J. (2015). Produtividade no setor de serviços. In F. De Negri \& L. R. Cavalvante (Eds.), Produtividade no Brasil: desempenho e determinantes (Vol. 2, pp. 277-300).

Banco Central do Brasil - BCB. Departamento Econômico - DEPEC. (2018). SGS: Sistema Gerenciador de Séries Temporais. Retrieved in 2018, March 27, from https://www3.bcb. gov.br/sgspub/localizarseries/localizarSeries.do?method=prepararTelaLocalizarSeries 
Barbosa Filho, F. D. H., \& Pessôa, S. D. A. (2014). Pessoal ocupado e jornada de trabalho: uma releitura da evolução da produtividade no Brasil. Revista Brasileira de Economia, 68(2), 149-169.

Barros, A. L. M. D. (1999). Capital, produtividade e crescimento da agricultura: o Brasil de 1970 a 1995 (Doctoral dissertation). Universidade de São Paulo.

Barros, G. S. C. (2016). Medindo o crescimento do agronegócio: bonança externa e preços relativos. In J. E. R. Vieira-Filho \& J. G. Gasques (Eds.), Agricultura, transformação produtiva e sustentabilidade (Cap. 8, pp. 219-250). Brasília: IPEA.

Barros, G. S. C., \& Castro, N. R. (2020). Exportações do agronegócio: faturamento e taxação cambial (Vol. 1). Piracicaba: Centro de Estudos Avançados em Economia Aplicada.

Barros, G. S. C., Carrara, A. F., Silva, A. F., \& Castro, N.R. (2020). Agronegócio e inflação (Vol. 1, No. 1). Piracicaba: Centro de Estudos Avançados em Economia Aplicada.

Bonelli, R. \& Veloso, F. (2012). Rio de Janeiro: crescimento econômico e mudança estrutural. In A.C. Pinheiro \& F. Veloso (Eds.), Rio de Janeiro: um estado em transição Rio de Janeiro: FGV.

Bonelli, R., \& Bacha, E. L. (2011). Crescimento brasileiro revisitado. In F. Veloso, P. C. Ferreira, F. Giambiagi \& S. Pessôa (Eds.), Desenvolvimento Econômico: uma perspectiva brasileira. Rio de Janeiro: Campus.

Brasil. Ministério do Trabalho e Educação - MTE. (2017). Relação anual de informações sociais. Brasília: MTE. Retrieved in 2018, September 10, from http://bi.mte.gov.br/bgcaged/login.php/

Brigatte, H., \& Teixeira, E. C. (2011). Determinantes de longo prazo do produto e da Produtividade Total dos Fatores da agropecuária brasileira no período 1974-2005. Revista de Economia e Sociologia Rural, 49(4), 815-836.

Buainain, A. M., Alves, E., Silveira, J. M. D., \& Navarro, Z. (2013). Sete teses sobre o mundo rural brasileiro. Revista de Política Agrícola, 22(2), 105-121.

Carvalheiro, N. (2003). Uma decomposição do aumento da produtividade do trabalho no Brasil durante os anos 90. Revista de Economia Contemporânea, 7(1), 81-109.

Castro, N. R., Barros, G. S. A. D. C., Almeida, A. N., Gilio, L., \& Morais, A. C. D. P. (2020). The Brazilian agribusiness labor market: measurement, characterization, and analysis of income differentials. Revista de Economia e Sociologia Rural, 58(1).

Castro, N. R., Barros, G. S.C, Almeida, A. N., Gilio, L., \& Morais, A. C.P (2017). Mercado de trabalho e rendimentos no agronegócio de Minas Gerais. Revista de Economia e Agronegócio, 15(3).

Cavalcante, L. R., \& De Negri, F. (2014). Evolução recente dos indicadores de produtividade no Brasil. In F. De Negri \& L. R. Cavalvante (Eds.), Produtividade no Brasil: desempenho e determinantes (Cap. 5, pp. 143-172). Brasília: IPEA.

Centro de Estudos Avançados em Economia Aplicada - CEPEA. (2017). Metodologia: PIB do agronegócio brasileiro: base e evolução. Piracicaba.

Ellery Junior, R. (2014). Desafios para o cálculo da produtividade total dos fatores. In F. De Negri \& L. R. Cavalvante (Eds.), Produtividade no Brasil: desempenho e determinantes (Cap. 2, pp. 53-86). Brasília: IPEA.

Freitas, R. E. (2014). Produtividade agrícola no Brasil. In F. De Negri \& L. R. Cavalvante (Eds.), Produtividade no Brasil: desempenho e determinantes (Cap. 12, pp. 373-410). Brasília: IPEA.

Fuglie, K. O., Wang, S. L., \& Ball, V. E. (Eds.). (2012). Productivity growth in agriculture: an international perspective. CABI.

Galeano, E., \& Feijó, C. (2013). A estagnação da produtividade do trabalho na indústria brasileira nos anos 1996-2007: análise nacional, regional e setorial. Nova Economia, 23(1), 9-50. 
Gasques, J. G., Bastos, E. T., Valdes, C., \& Bacchi, M. R. P. (2012a). Produtividade da agricultura brasileira e os efeitos de algumas políticas. Revista de Política Agrícola, 21(3), 83-92.

Gasques, J. G., Bastos, E. T., Valdes, C., \& Bacchi, M. R. P. (2012b). Total factor productivity in Brazilian agriculture. In K. O. Fuglie, S. L Wang \& V. E. Ball (Eds.), Productivity growth in agriculture: an international perspective (pp. 145-160).

Guilhoto, J. J. M., \& Sesso Filho, U. A. (2005). Estimação da matriz insumo-produto à partir de dados preliminares das contas nacionais. Economia Aplicada, 9(2), 277-299.

Guilhoto, J. J. M., \& Sesso Filho, U. A. (2010). Estimação da matriz insumo-produto utilizando dados preliminares das contas nacionais: apliçção e análise de indicadores econômicos para o Brasil em 2005. Economia \& Tecnologia, 23, 53-62.

Instituto Brasileiro de Geografia e Estatística - IBGE. (2015). Nota técnica: principais diferenças metodológicas entre as pesquisas PME, PNAD e PNAD contínua. Rio de Janeiro.

Instituto Brasileiro de Geografia e Estatística - IBGE. (2017a). Contas nacionais trimestrais. Retrieved in 2018, September 10, from http://www.ibge.gov.br/home/estatistica/indicadores/pib/defaultcnt.shtm

Instituto Brasileiro de Geografia e Estatística - IBGE. (2017b). Índice Nacional de Preços ao Consumidor Amplo - IPCA. Retrieved in 2018, September 10, from https://sidra.ibge.gov. br/pesquisa/snipc/ipca/tabelas/brasil/fevereiro-2018

Instituto Brasileiro de Geografia e Estatística - IBGE. (2017c). Pesquisa industrial mensal: produção física. Retrieved in 2018, September 10, from https://sidra.ibge.gov.br/pesquisa/ pim-pf-brasil/tabelas

Instituto Brasileiro de Geografia e Estatística - IBGE. (2017d). Pesquisa Nacional por Amostra de Domicílios - PNAD. Retrieved in 2018, September 10, from http://www.ibge.gov.br/home/ estatistica/populacao/trabalhoerendimento/pnad2015/default.shtm

Instituto de Pesquisa Econômica Aplicada - IPEA. (2020). IPEAdata - salário mínimo real. Retrieved in 2020, March 27, from http://www.ipeadata.gov.br/Default.aspx

Jacinto, P. D. A., \& Ribeiro, E. P. (2015). Crescimento da produtividade no setor de serviços e da indústria no Brasil: dinâmica e heterogeneidade. Economia Aplicada, 19(3), 401-427.

Maia, A. G., \& Sakamoto, C. S. (2014). A nova configuração do mercado de trabalho agrícola brasileiro. In O mundo rural no Brasil do século 21 (pp. 591-620).

Mello, P. H. S., \& Barbosa Filho, F. H. (2014). Nota sobre o custo unitário do trabalho no Brasil (Nota Técnica IPEA, No. 56).

Organization for Economic Co-Operation and Development - OECD. (2010). OECD manual: measuring productivity.

Pastore, A. C., Gazzano, M., \& Pinotti, M. C. (2012). Por que a produção industrial não cresce desde 2010. In O futuro da indústria no Brasil: desindustrialização em debate. Rio de Janeiro: Civilização Brasileira.

Rezende, G. C. D (2006). Políticas trabalhista, fundiária e de crédito agrícola no Brasil. Revista de Economia e Sociologia Rural, 44(1), 47-78.

Silva, A. M., Carvalho, A. Y., Rocha, B. F. F. D., \& Bevilaqua, G. S. (2017). Modelagem da Relação entre a Inflação do Consumidor e a Inflação do PIB (Carta de Conjuntura, 16 p.). Instituto de Pesquisa Econômica Aplicada (Ipea).

Squeff, G. C. (2012). Desindustrialização: luzes e sombras no debate brasileiro (Texto para Discussão, No. 1.747). Brasília: IPEA. 
Veloso, F. A., Matos, S. M., Ferreira, P. C., \& Coelho, B. P. (2017). O Brasil em comparações internacionais de produtividade: uma análise setorial. In R. Bonelli, F. Veloso \& A. C. Pinheiro (Eds.), Anatomia da produtividade no Brasil. Rio de Janeiro: Elsevier: FGV/IBRE.

Received: February 08, 2020.

Accepted: February 18, 2021.

JEL Classification: E24; Q13 


\section{Appendix 1-CNAE-Domicile descriptions and codes, agrobusiness activities and method of obtaining}

\begin{tabular}{|c|c|c|c|}
\hline $\begin{array}{l}\text { Description CNAE-domicile } \\
\text { (PNAD) }\end{array}$ & $\begin{array}{l}\text { Code CNAE- } \\
\text { domicile }\end{array}$ & $\begin{array}{l}\text { Agrobusiness } \\
\text { activity }\end{array}$ & $\begin{array}{l}\text { Method of } \\
\text { obtaining }\end{array}$ \\
\hline \multicolumn{4}{|c|}{ Input segment } \\
\hline $\begin{array}{l}\text { Manufacture of } \\
\text { pharmaceutical products }\end{array}$ & 24020 & $\begin{array}{c}\text { Manufacture of Veterinary } \\
\text { Medicines }\end{array}$ & Coefficients \\
\hline $\begin{array}{l}\text { Manufacture of chemicals and } \\
\text { chemical products }\end{array}$ & 24090 & $\begin{array}{c}\text { Manufacture of fertilizers } \\
\text { and pesticides }\end{array}$ & Coefficients \\
\hline $\begin{array}{l}\text { Manufacture of machinery } \\
\text { and equipment }\end{array}$ & 29001 & $\begin{array}{l}\text { Manufacture of agricultural } \\
\text { machinery and equipment }\end{array}$ & Coefficients \\
\hline \multicolumn{4}{|c|}{ Primary segment } \\
\hline $\begin{array}{l}\text { Agriculture, livestock, fishing, } \\
\text { and forestry activities }\end{array}$ & $1101-5002$ & $\begin{array}{l}\text { Agriculture, livestock, fishing, } \\
\text { and forestry activities }\end{array}$ & Directly \\
\hline \multicolumn{4}{|c|}{ Agroindustry segment } \\
\hline $\begin{array}{l}\text { Manufacture of food products } \\
\text { and beverages }\end{array}$ & $15010-15055$ & $\begin{array}{l}\text { Manufacture of food } \\
\text { products and beverages }\end{array}$ & Directly \\
\hline $\begin{array}{l}\text { Manufacture of tobacco } \\
\text { products }\end{array}$ & 16000 & $\begin{array}{l}\text { Manufacture of tobacco } \\
\text { products }\end{array}$ & Directly \\
\hline Manufacture of textiles & 17001 and 17002 & $\begin{array}{l}\text { Manufacture of natural- } \\
\text { based textiles }\end{array}$ & Coefficients \\
\hline $\begin{array}{l}\text { Manufacture of wearing } \\
\text { apparel }\end{array}$ & 18001 and 18002 & $\begin{array}{l}\text { Manufacture of natural- } \\
\text { based wearing apparel }\end{array}$ & Coefficients \\
\hline $\begin{array}{l}\text { Manufacture of leather and } \\
\text { related products and footwear }\end{array}$ & $\begin{array}{c}19011,19012 \text { and } \\
19020\end{array}$ & $\begin{array}{l}\text { Manufacture of leather } \\
\text { and related products and } \\
\text { leather footwear }\end{array}$ & Coefficients \\
\hline $\begin{array}{l}\text { Manufacture of wood and of } \\
\text { products of wood and cork, } \\
\text { except furniture }\end{array}$ & 20000 & $\begin{array}{l}\text { Manufacture of wood and } \\
\text { of products of wood and } \\
\text { cork, except furniture }\end{array}$ & Directly \\
\hline $\begin{array}{l}\text { Manufacture of paper and } \\
\text { paper products }\end{array}$ & 21001 and 21002 & $\begin{array}{l}\text { Manufacture of paper and } \\
\text { paper products }\end{array}$ & Directly \\
\hline Alcohol production & 23400 & Alcohol production & Directly \\
\hline $\begin{array}{l}\text { Manufacture of furniture and } \\
\text { other industries }\end{array}$ & 36010 & $\begin{array}{l}\text { Manufacture of wood } \\
\text { furniture }\end{array}$ & Coefficients \\
\hline \multicolumn{4}{|c|}{ Agro-services segment } \\
\hline Wholesale and retail trade & $53010-53113$ & $\begin{array}{l}\text { Agrobusiness wholesale } \\
\text { and retail trade }\end{array}$ & Coefficients \\
\hline Transportation and storage & $60010-62000$ & $\begin{array}{c}\text { Agrobusiness } \\
\text { transportation and storage }\end{array}$ & Coefficients \\
\hline $\begin{array}{l}\text { Printing and reproduction of } \\
\text { recorded media }\end{array}$ & 22000 & Other agrobusiness services & Coefficients \\
\hline $\begin{array}{l}\text { Accommodation and Food } \\
\text { service activities }\end{array}$ & $55010-55030$ & Other agrobusiness services & Coefficients \\
\hline $\begin{array}{l}\text { Attached and auxiliary } \\
\text { activities of transport and } \\
\text { travel agencies }\end{array}$ & $63010-63030$ & Other agrobusiness services & Coefficients \\
\hline $\begin{array}{l}\text { Postal and courier activities } \\
\text { and Telecommunications }\end{array}$ & 64010 and 64020 & Other agrobusiness services & Coefficients \\
\hline Public Administration & $75011-75020$ & Other agrobusiness services & Coefficients \\
\hline Other activities & $65000-74090$ & Other agrobusiness services & Coefficients \\
\hline
\end{tabular}

Source: author's results based on Centro de Estudos Avançados em Economia Aplicada's (2017) definition and Castro et al. $(2017,2020)$ 


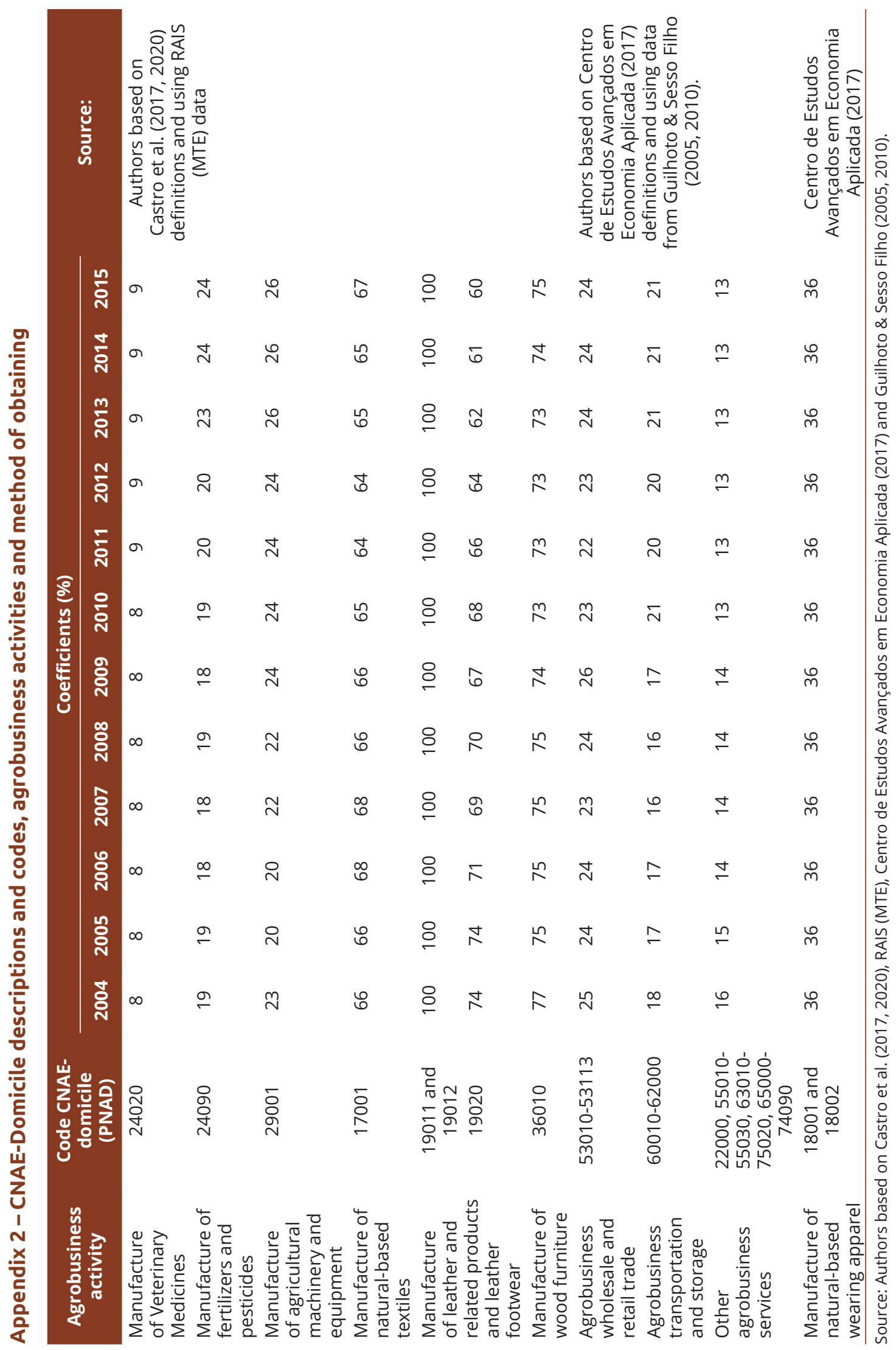




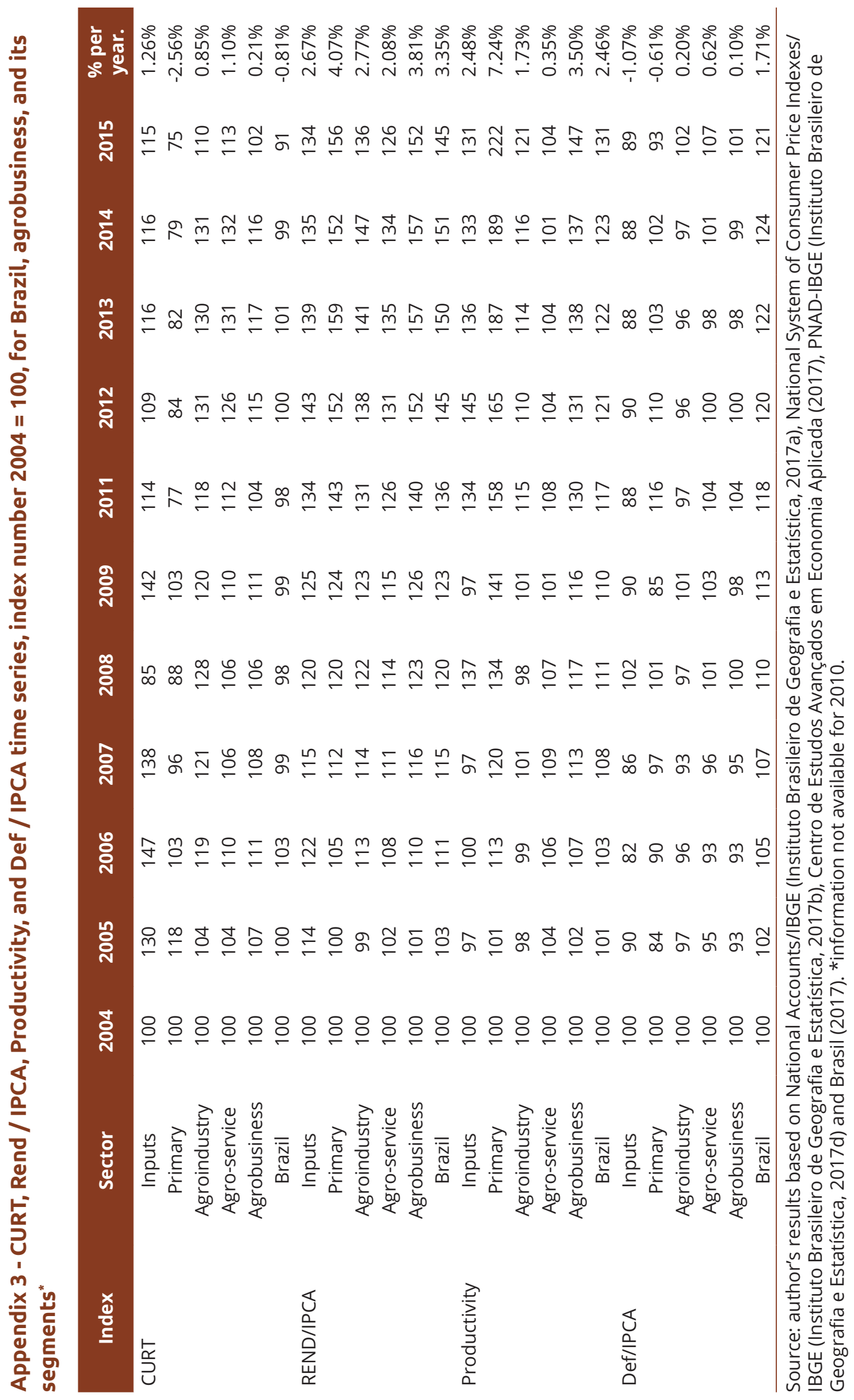

